
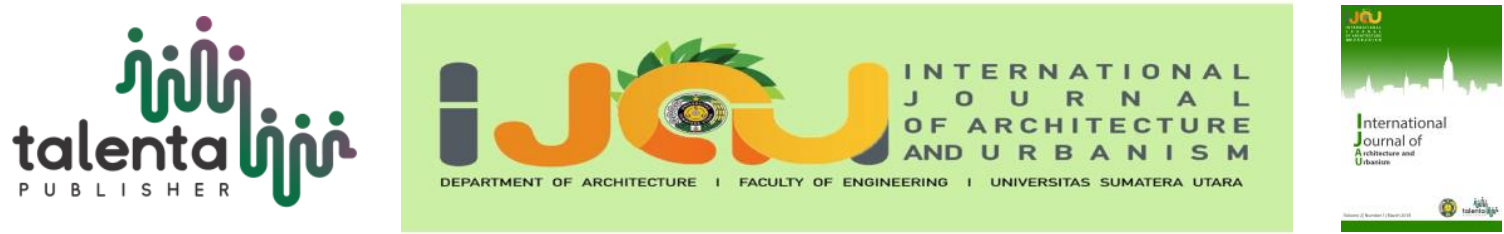

\title{
Youth and Creativity Center Medan-Selayang (With Neo-Vernacular Architecture Design Approach)
}

\author{
Imam Faisal Pane ${ }^{1 *}$, Hilda Masito Tanjung ${ }^{1}$ \\ ${ }^{I}$ Department of Architecture, Universitas Sumatera Utara, Medan, Indonesia
}

\begin{abstract}
The construction of facilities such as Youth and Creative Center is to meet the needs facilities and urban infrastructure. As a container that enables youth to engage in positive activities to appreciate themselves, exchanging ideas and channeling energy, hobbies, and ideas shared by local youth. Strategically located on the outskirts of Medan City and located in the city center of education, the presence of the youth center is expected to take a role in the local moral and social control of the teenager which has increased annually, and hopes to someday cope with the social problems that often arise; such as fights between students, theft, vandalism, and drug with prevention to turn into a quality generation. With the existence of Youth and Creativity Center Medan-Selayang, is expected to adapt to the characteristics of teenagers who are always evolving progress of time, can interact, and be creative with others positively and in an integrated environment between education, recreation, and sport, which is useful and convenient to use. Teenagers Youth and Creativity Center is using the Neo-Vernacular Architecture design approach, which impressed magnificent and sturdy. Therefore the concept of the shape taken is a square geometric shape, and the overall shape shows the symmetrical shape.
\end{abstract}

Keyword: adolescents, creativity, neo-vernacular, symmetrical

\section{Introduction}

Teenagers today have social inequalities, the emotional upheaval that occurs in adolescents should be avoided from various influences, such as neighborhoods, family, school, and peers, as well as activities that do in everyday life. This is evident from how often teenagers do activities outside of the school to fill their spare time; useful activities are done according to his talents and interests. There are also those who fill their time with unfavorable activities, such as fighting, wild racing, sexual freedom, crime, even drug use [1].

Seeing the problems to the potential of the adolescent, as well as the need for a means to accommodate the activities of coaching and self-development teenagers, leisure activities with positive activity is one way to avoid adolescents from harmful things [2]. Therefore, in the city of Medan precisely in the District of Medan-Selayang planned a building Youth and Creativity

\footnotetext{
*Corresponding author at: Department of Architecture, Faculty of Engineering, Universitas Sumatera Utara,

Jalan Perpustakaan Gedung J07, Medan 20155, Indonesia

E-mail address: imamfpane@gmail.com
} 
Center with various facilities in it. The planning and design of Youth and Creative Center of Medan-Selayang are expected to be by with the characteristics of adolescents who always develop following the advancement of time, so can interact, create, and play positively and directed in an integrated environment between educational, recreational and sports activities. Useful and convenient to use. Based on the location of the design, that being focus is the teenage group (15-29 years) is in the District of Medan-Selayang and surrounding areas. Among them, Medan-Sunggal Sub-district, Medan-Baru, Medan-Polonia, Medan-Johor, MedanHelvetia, and Medan-Tuntungan. If you look at existing data, then in the year 2015 the number of people who teenagers (15-29 years old) with coverage area Medan-Selayang and seven subdistricts are 282,387 people from a total of 2,210,624 people in the city of Medan, or about $12 \%$ of Medan's population.

\section{Literature Review}

\subsection{Object Description}

Understanding the Youth and Creative Center Medan-Selayang is a means and infrastructure provided as a safe and comfortable place to gather/socialize doing activities that suit your interests and talent of teenagers in the arts, sports, and creativity in a creative environment 15 to 29 years.

\subsection{Location and Site}

Location of Youth and Creativity Center is in the Sub-district of Medan-Selayang. Based on RTRW Medan-Selayang, sub-district is one of the districts located in the city of Medan which has an area of approximately $23.89 \mathrm{~km}^{2}$ or $4.83 \%$ of the total area of Medan City. This district's height is $26-50$ meters above sea level.

Medan-Selayang sub-district is a fraction of Medan-Baru, Medan-Sunggal and MedanTuntungan sub-districts.Concerning the graphic illustration related to the location of the project as follows (Figure 1).

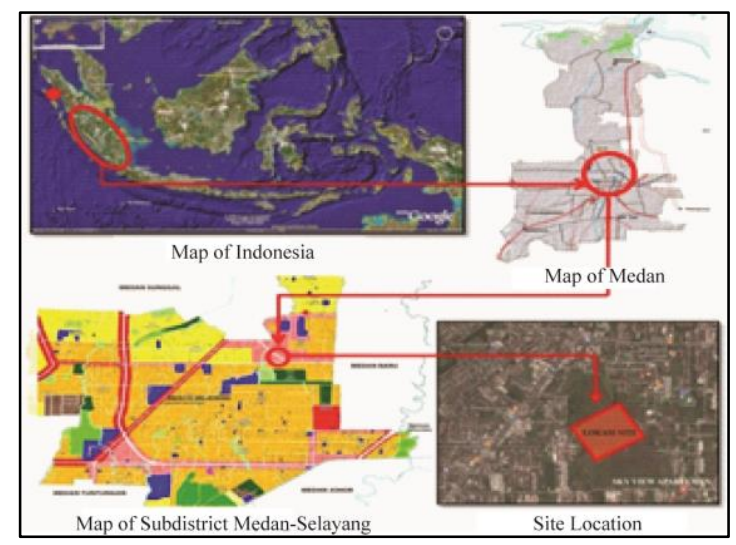

Figure 1. Maps of Location Site

(Source: Google Earth and author 2018) 


\subsection{Theme Review}

In today's modern era emerging many new technologies are endless, no exception in the field of architecture. The technology is not only regarding new materials but also regarding how to build, the purpose of building, etc. so that over time the original architecture of an area abandoned for various reasons. There are several views that traditional building is old-fashioned or outdated. That is what makes the original buildings of an area threatened to perish. Therefore there is a need for business and awareness to preserve the traditional buildings. The unavoidable behavior of an area from cultural change, and people's mindset [5].

By applying the Neo-Vernacular Architecture to the building, creating a modern building but not leaving a traditional building of an area. The theme applied to the design of the Youth Center and the Center for Creativity is the theme of Neo-Vernacular Architecture. Because the culture or ethnic dominant in Medan City is Malay, so the planning of the building emphasizes the Neo-Vernacular concept with the culture or ethnic Malay contained in Medan City will be lifted. Neo-Vernacular Architecture is an architecture whose concept in principle considers normative, cosmological, local culture in community life and harmony between buildings, nature and the environment. Post-Modern Architecture and its flow incorporated into traditional with non-traditional, modern with half non-modern, old fusion with new (Table 1).

Table 1. Comparison of Traditional Architecture, Vernacular and Neo-Vernacular

\begin{tabular}{|c|l|l|l|l|}
\hline No & Comparison & \multicolumn{1}{|c|}{ Traditional } & \multicolumn{1}{c|}{ Vernacular } & \multicolumn{1}{c|}{ Neo-Vernacular } \\
\hline 1. & Ideology & $\begin{array}{l}\text { Formed by tradition passed } \\
\text { down from generation to } \\
\text { generation, based on local } \\
\text { culture and conditions. }\end{array}$ & $\begin{array}{l}\text { Is a hereditary tradition but is outside } \\
\text { physical or nonphysical influence, } \\
\text { forms of development traditional } \\
\text { architecture. }\end{array}$ & $\begin{array}{l}\text { Application of existing } \\
\text { architectural elements and } \\
\text { then a little or a lot of having } \\
\text { an update to modern work. }\end{array}$ \\
\hline 2. & Principle & $\begin{array}{l}\text { Closed from the changing } \\
\text { times, adrift on one the } \\
\text { culture of the region, and has } \\
\text { a thick religious rule and } \\
\text { norm. }\end{array}$ & $\begin{array}{l}\text { Architecture grows every time where } \\
\text { it is, reflect the environment, culture, } \\
\text { and history of the area. The } \\
\text { transformation of a homogenous } \\
\text { cultural situation into a heterogenous } \\
\text { cultural situation. }\end{array}$ & $\begin{array}{l}\text { Neo-vernacular architecture } \\
\text { aims to preserve locally } \\
\text { formed elements empirical by } \\
\text { tradition and develop it into a } \\
\text { style modern. }\end{array}$ \\
\hline Design Ideas & $\begin{array}{l}\text { More concerned facade or } \\
\text { shape, ornament as a } \\
\text { necessity. }\end{array}$ & $\begin{array}{l}\text { Ornaments as complementary, leave } \\
\text { local values but can serve } \\
\text { community activities in the. }\end{array}$ & $\begin{array}{l}\text { Neo-vernacular has a more } \\
\text { modern architectural design }\end{array}$ \\
\hline
\end{tabular}

Source: ([4] Irawan, D, 2017)

\section{Methodology}

A project can be planned and executed through a process; the process is known by the method to facilitate the designer in designing the building, one of them through analytical, and descriptive. The descriptive, analytical method is a method that contains an explanation or exposure to the condition of the phenomenon that occurs. These stages begin by describing/illustrating the fact that is happening in the field, then those supporting this method are problem analysis and literature study theory [3]. Techniques of collecting data in the form of literature studies that have a relationship with the title and themes discussed in the thesis to strengthen the facts naturally, field observation (survey), conducted by observation and data 
collection directly on site by knowing, and feeling the atmosphere and discussion with group members to open minds and add ideas to design and determine what external programs will be created.

\section{Result and Discussion}

\subsection{Site Analysis}

The location of the Youth and Creativity Center at Jl. Abdul Hakim, Medan-Selayang Subdistrict, North Sumatera. Precisely in Kampung Susuk which is a residential area. This area according to RDTR Medan City is a commercial area, education, and settlement. The site on this project is a square with an overall area of $3.2 \mathrm{Ha}$ (multi-period) with an allotment of land as the center of trade/business activity and education center. The secondary arterial road is 26 meters, has a KDH of $20 \%$ and a KDB of $50-70 \%$.

The condition at the design site currently consists of vacant land in the form of rice field, with most of the design site is the function of residential housing, and there is the University of North Sumatra as the supporting factor of design location. The location area is located on the edge of the city and is in the middle of the settlement, so the designs on the north, east, and west are directly adjacent to the residential and residential areas, while on the south by the existing Sky View Apartments that are currently under construction.

The effect of the site layout in planning the Youth and the Center for Creativity is essential to know the environmental factors that exist around the site to ensure proper functioning of the building against the surrounding buildings. So used land use analysis at a radius of $500 \mathrm{~m}$, the circumstances surrounding the site surrounded by rice fields and there is USU campus as a center of education and commercial areas. However, within a radius of $1 \mathrm{~km}$ there are homes around the area, be it a high-density housing, as well as medium-density housing. Based on RUTR of Medan City, included in the zone of commercial planning and educational center. And close to plantation area and urban forest area.

\subsection{Basic Concept}

Rearrangement of Youth and Creative Centerbasedon symmetrical pattern with a definite axis. This symmetrical pattern is applied so that the Youth Arena building looks majestic and sturdy. Where the part of the mass affected by the axis is the catchment point or has the highest value compared with the flanking masses. The concept used to realize the character of the place that gives the impression of fun for the visitors is to design an attractive building by applying of Neo-Vernacular architecture and provide comfort for people to perform activities in this building. Concerning the graphic illustration related to the basic concept of the project as follows (Figure 2). 


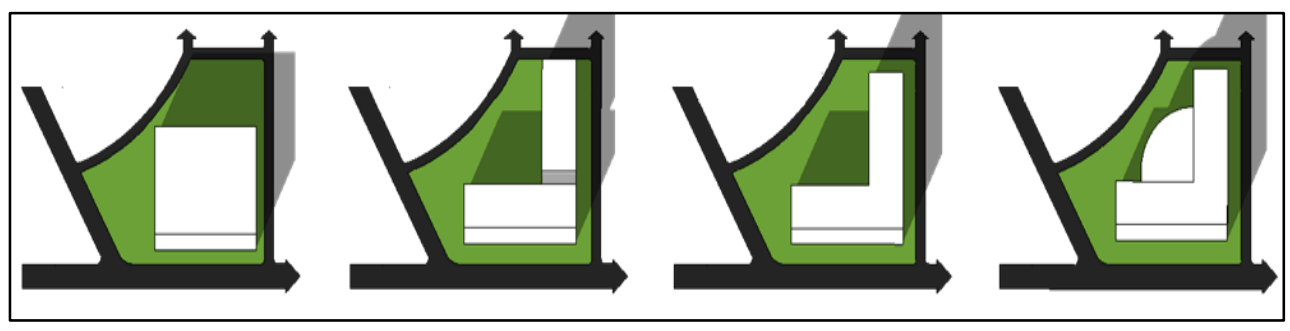

Figure 2. The Concept of Mass Building Formation

In the first picture is the initial mass formation of a square, the mass shape is in accordance with the site form is a square shape with a slight arch on one side. In the second picture, building masses are broken down into two masses, that is the horizontal square and vertical square masses, the separation of these two masses aims to facilitate the preparation of space programs. In the third stage, the separated mass formation is united into a unified building. And in the final stage, the empty part of the two masses will be closed by the time that is right in the middle of the two square masses; the mass serves as a performance space.

\subsection{Youth Center Design Approach}

The emphasis of design is the neo-vernacular architecture. Neo-vernacular architecture can be realized in the following way: The appearance of a grand and monumental as a feature of durability. The roof is extensive in response to the local climate (tropical climate). With the size of this large roof; to improve security, can reduce the air is hot during the day and not too cold at night. Application of a touch of golden yellow paint as a characteristic of Malay, for building Youth and Center of Creativity Medan-Selayang can give closeness to the surrounding environment. As for the design of the future, the concept of form, appearance of the building, as well as its structure and utility.

\subsection{Spatial Building}

Youth and Creative Center Medan-Selayang consists of two unified masses of buildings. The main building consists of 4 floors, while the gym and main building are connected. Design of building mass structure is with the symmetrical pattern with clear axis lines. Zoning distribution on buildings based on private properties - semi-private - public - service. The concept of space used is the nature of space which is getting to the upper floor; then it will be more private.

On the first floor, the main building consists of public and service zones, where there are only retail-retail and mini-libraries open to the public, there are two escalators, and there are four lifts which 2 of them are lifts directly to the showroom to facilitate the visitors. On the second floor consists of public, semi-public, private, and service zones. There is a classroom, a teaching room, a gallery, and a dance practice room. On the third floor, the space zone consists of private, semi-private, public and service. The rooms on the third floor are almost identical to the rooms on the second floor, such as classrooms, gym room, management room, and assembled 
space. While on the fourth floor, is a semi-private space zone, public, and service. The space on the fourth floor is a performance space used for performances for the theater class. The other parties can also rent the showroom. Concerning the graphic illustration related to the spatial building of the project as follows (Figure 3).

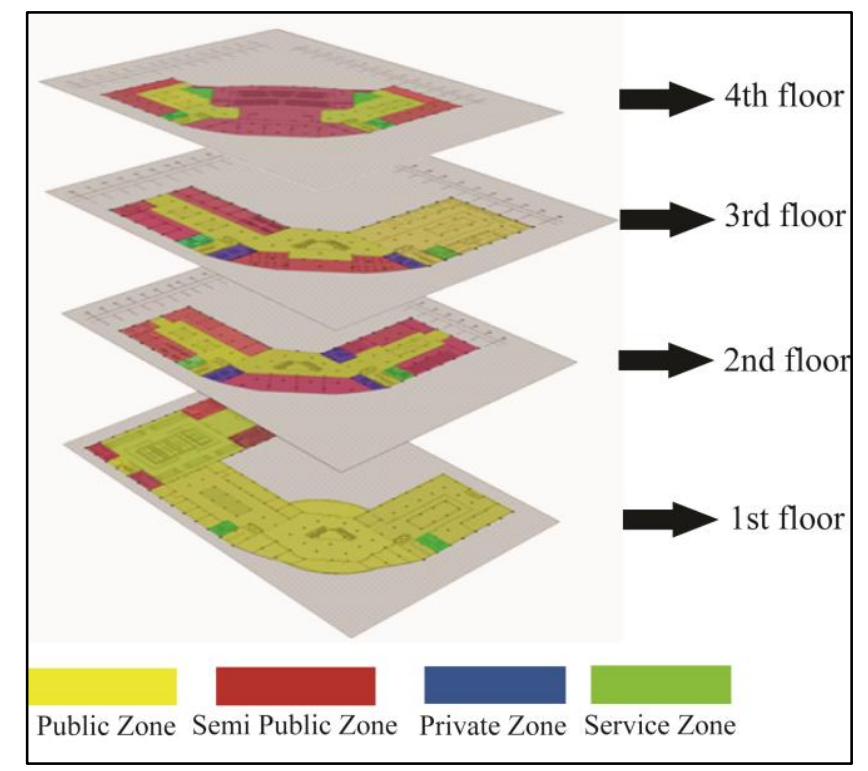

Figure 3. Zoning Building

\subsection{Aesthetic Shapes}

Youth and Creative Center is a building that is educative and recreational, so the style of the building should be impressed magnificent. That's why the concept of the form taken is a square geometric, and all of them show symmetrical shape. For placement and building orientation obtained from the analysis of tread and catchment point analyzed from the direction of green open space on the sky bridge. Where the building part the affected axis has the highest value and is used for the function of principal activity. For the roof of the building adopted a roof shield and pyramid roof on both wings. Concerning the graphic illustration related to the aesthetic shapes of the project as follows (Figure 4).

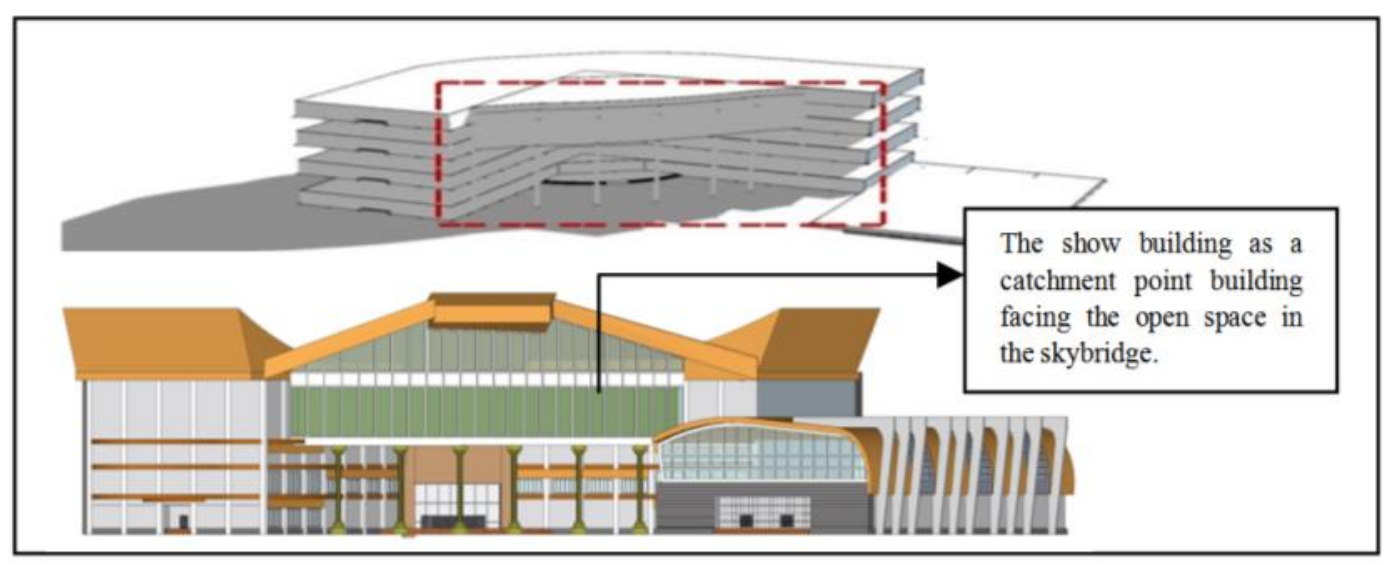

Figure 4. Concept Form 
In the main building, the roof used is a storied roof that follows the shape of buildings that rise, and there is also a flat roof, roof coverings of wood to create a natural impression on the building and ornaments on the roof are made of storied and decorated as well as ventilation. As for the shape of the building made more modern to give the impression Neo-Vernacular. The material used for the building is ACP (Aluminum Composite Panel) to give a modern impression.

\subsection{Concept of Outer}

The vehicle circulation using a centralized system, the center of the vehicle is because the road is in the form of a circle. The vehicle path is from the entry point of the site directly to the basement or the drop-off area, then also a road network with a basement exit that can go directly to the vehicle parking area or head out of the site. Concerning the graphic illustration related to the concept of outer of the project as follows (Figure 5).

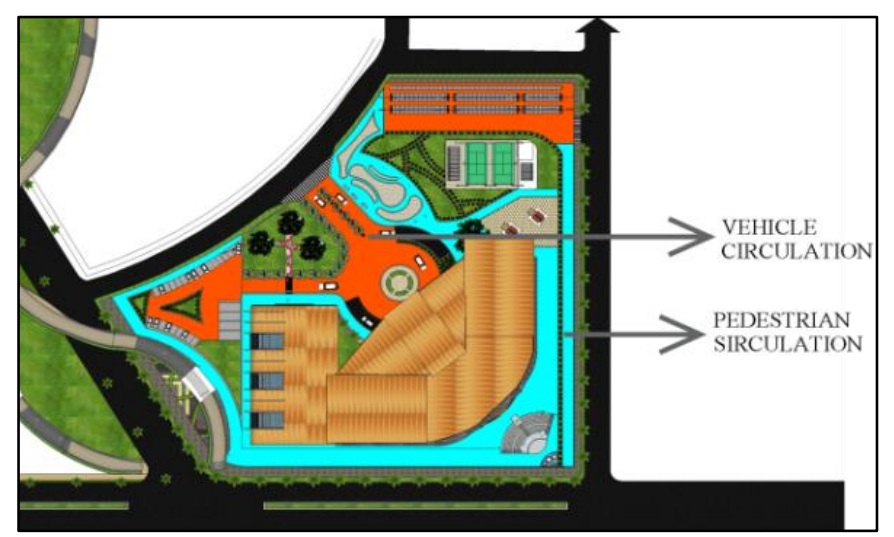

Figure 5. The Concept of Outer Space

Prefer pedestrian area circulation in the planning of the Youth and Creative Center MedanSelayang. For the outer space setting system, it tends to be linear with vista center of the building is a plaza (a gathering place for many people) located in the main building in the form of nodes (triangulation), thus creating different sequences in every outer space in the planning. All existing facilities at the Youth and Creative Center Medan-Selayang use sidewalks that act as pedestrian circulation. The pavement consists of Mosaic with yellow, red, and orange colors gives a natural impression. The parking of motor vehicles and buses on site is on the ground; this is because most of the bikers are students/students who always want instant adolescent habits, while to park a car vehicle in the basement.

\subsection{Concept Appears}

The visible in the Youth and Creativity Center is to use secondary skin and natural stone on the back side of the building, as an action to reduce the level of sunlight that can interfere with the thermal comfort of the building. On the facade of the building, the roof coverings using wood 
materials using lightweight steel roof truss. The showhouse is a catchment point that has the highest value compared to both sides of the building wing.

The shape of the building design is like a house stage, on the front of the building serves as a performance building located on the fourth floor. Theater building on the fourth floor can show the impression of a house on stilts with the support of Malay columns emblazoned in front of the building, to show a typical neo-vernacular architecture. Concerning the graphic illustration related to the concept appears of the project as follows (Figure 6).

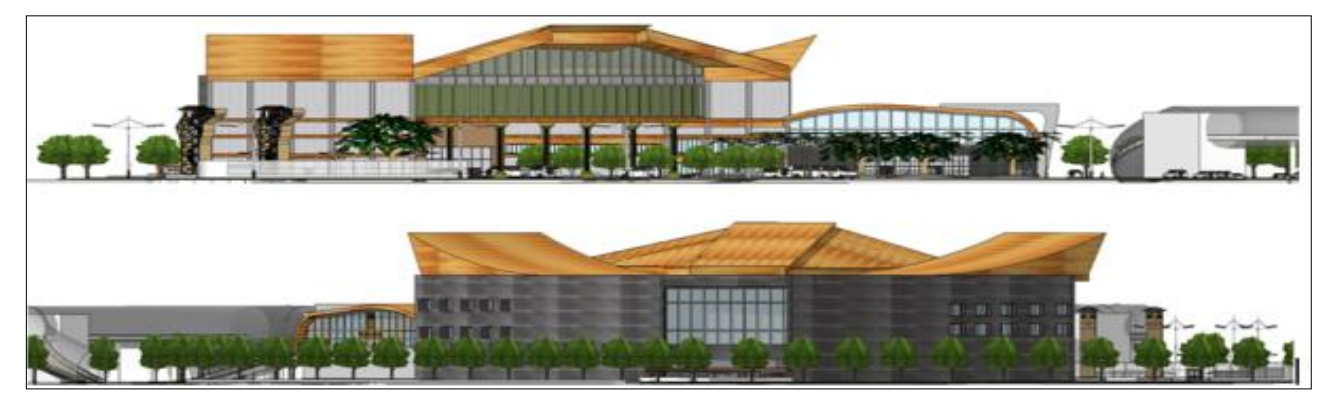

Figure 6. The Concept of Mass of The Main Building

\subsection{Building Structure}

The building structure of Youth and Creative Center of Medan-Selayang consists of substructure that is, using pile foundation and upper structure which includes leg structure consists of the grid structure and wide span structure, concrete floor structure, steel roof frame structure, and structure brick wall as structural reinforcement. Concerning the graphic illustration related to the concept of outer of the project as follows (Figure 7).

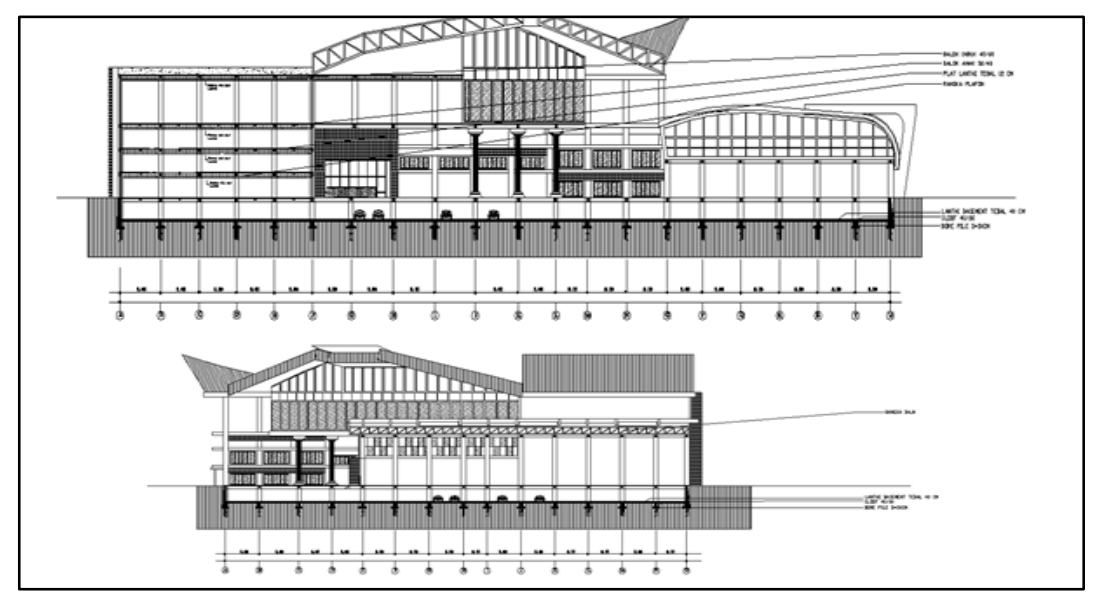

Figure 7. Building Structure

\subsection{Architecture Design}

The application of the neo-vernacular theme to the design of the Youth and Creativity Center is a close relationship between the outer-in-building outer space view and the surrounding elements with the function of the building but remains united and in touch with the local 
community. The neo-vernacular architecture will be the theme in the Youth and Creativity Center design. As for the two concepts of the mass footprint in the youth arena with three types of functions namely, the central building of creativity, theater, and the gym (Figure 8).

Among users in the Youth and Creativity Center is divided into 4 groups: Visitor Activities are people who come to the Youth Center to conduct certain activities with various facilities inside and outside the building, including students, community members, or ordinary people who want to use the facility, whether it is education and recreation, therefore needed a circulation system in a harmonious and manageable building to create a comfortable atmosphere for visitors. Management activities and employees are the workers responsible for managing the scope of Youth Arena, both administratively and physically. Tenant activities (cafe and retail) are the managers responsible for the business provided, to provide comfort and security for tenants' cafes and restaurants. While the service activities are responsible for monitoring the hygiene of the building, in addition to the cleanliness of the perpetrator is also responsible for serving the needs of employees during work. Concerning the graphic illustration related to design of the project as follows (Figure 8).

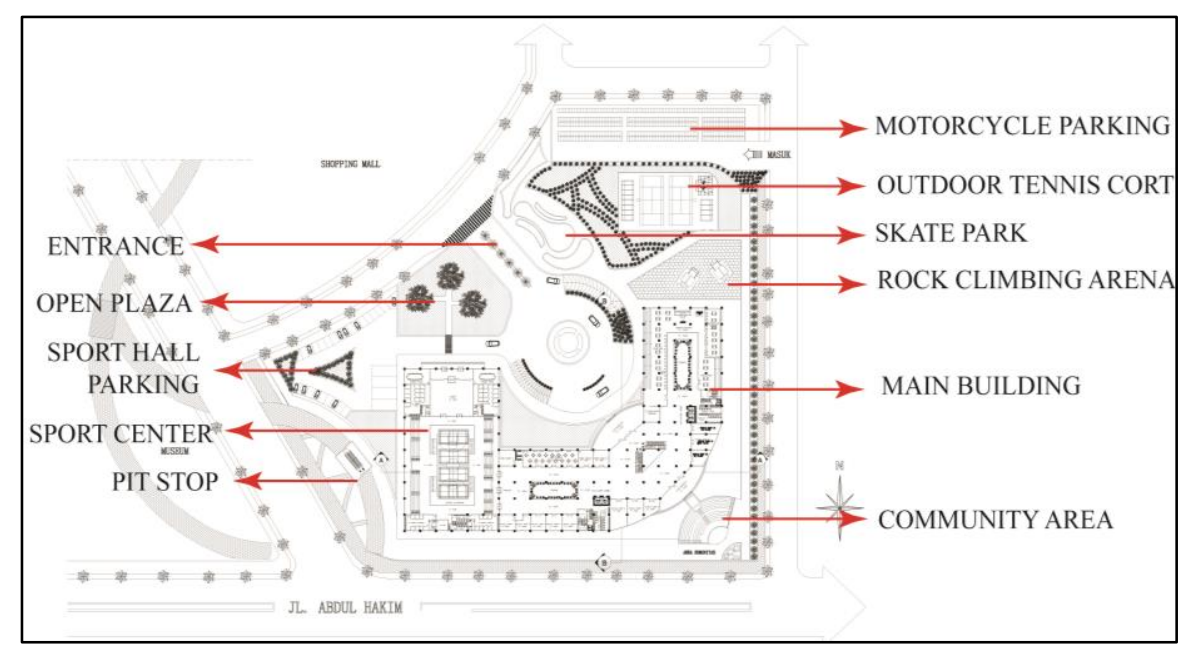

Figure 8. Site Plan

This is the position of view which we passed as we entered the building of Youth and Creativity Center of Medan-Selayang. Upon entering the Medan-Selayang Youth Area we will see in number 1, we can go directly to the basement area or the drop-off area located between the main building and the sports hall. At number 2 there is an open plaza for discussion or rest. At number 3 is a parking area for vehicles that use the gym. At number 4 is a sports building located on the right side of the main building. At number 5 is a pit stop on from the sky bridge that serves to connect to four buildings in one area; the sky bridge stop area is in each spot within the design area. 
At number 6 is a motorcycle parking area for visitors, the parking area located to the west of the main building. At number 7 is an outdoor tennis court as a supporting facility of the arena. At number 8 and number 9 are respectively skating rink, and rock climbing areas are supporting facilities. At number 10 is the main building of the Youth and Creativity Center, the main building is symmetrical with the impression of sturdy and majestic. Because there is green open space in the planning area, so the oriented showroom faces it as a catch point with a high value. And number 11 is a community gathering place as supporting facilities for discussion or exchange of thoughts.

\section{Conclusion}

The Youth and Creativity Center use the concept of emphasis on Neo-Vernacular Architecture design. The site area of 3.2 ha with building area is $11,082 \mathrm{~m}^{2}$. The design of the building uses a symmetrical pattern with a clear axis of the arrangement of building mass. This symmetrical pattern is applied so that the Youth and Creativity Center can seem majestic and sturdy. Therefore, in the planning of Youth and Creativity Center is an educative, creative, and recreational building that must be impressed magnificent and sturdy. Therefore the concept of the shape taken is a square geometric shape, and the overall shape shows the symmetrical shape. For placement and building orientation obtained from the analysis of the tread and catchment point analyzed from the direction of green open space found on the sky bridge. Where part of the affected building has the highest value and is used for the main activity compared to the flanking wing building. For the roof of the building, adopted the roof shield and pyramid. The building structure of the Youth Center and Creativity Center consists of substructures, namely using pile foundation and upper structure including leg of grid structure, concrete floor structure, and steel roof frame structure with the metal roof covering, using dilation.

\section{Acknowledgment}

This research is part of the requirement to obtain a bachelor's degree in Architecture Department, Universitas Sumatera Utara.

\section{REFERENCES}

[1] E. U. Jannah. Hubungan Antara Self-Efficacy Dan Kecerdasan Emosional Dengan Kemandirian Pada Remaja. PERSONA: Jurnal Psikologi Indonesia, 2(3). 2013.

[2] Soetjiningsih. Tumbuh Kembang Remaja dan Permasalahannya. Jakarta: Sagung Seto. 2014.

[3] Sugiyanto. Metodelogi Penelitian. Surakarta: UNS Press. 2012.

[4] D. Irawan. Resort Hotel Danau Singkarak Sumatera Barat (Penekanan Arsitektur Neo Vernakular). Doctoral dissertation, Universitas Muhammadiyah Surakarta. 2017.

[5] M. Rashid and D. R. Ara. Modernity in tradition: Reflections on building design and technology in the Asian vernacular. Frontiers of Architectural Research, 4(1), 46-55. 2015. 